\title{
Some of issues of endemic species reproductive biology of Southern Siberia Hedysarum L.
}

\author{
Nina Karnaukhova ${ }^{1 *}$, Inessa Selyutina ${ }^{1}$, and Serafima Syeva ${ }^{2}$ \\ ${ }^{1}$ Central Siberian Botanical Garden SB RAS, 630090 Zolotodolinskaya Str., 101, Novosibirsk, \\ Russia \\ ${ }^{2}$ Federal Altai Scientific Center for Agrobiotechnology, 656910 the village of Scientific town, 35, \\ Barnaul, Russia
}

\begin{abstract}
The seed productivity of endemic species of the genus Hedysarum L. in southern Siberia was studied. It is established that the reproduction of these species is carried out only by seed. Flowering occurs in June, the number of flowers in the inflorescence ranges from 12.3 to 19.1. The efficiency of fruit formation ( $\%$ of the set beans from the number of flowers) differs significantly: the maximum values are marked for $H$. austrosibiricum, $H$. turczaninovii and $H$. sangilense (90.7-74.1\%), the minimum values are marked for the rare $H$. minussinense, $H$. chaiyrakanicum, H. zundukii (35.3-47.2\%). A decrease in the number of seeds that are set compared to the number of ovules, caused by various reasons, leads to a significant decrease in the RSP compared to the PSP. The percentage of semenification in the studied species is highest in the endemics $H$. austrosibiricum, $H$. sangilense and $H$. turczaninovii (56.5$45.1 \%$ ), the minimum - in the rare $H$. zundukii, $H$. minussinense and $H$. chaiyrakanicum $(9.8-36.5 \%)$.
\end{abstract}

In the opinion of Levina R.V. [1], species reproductive biology is a boarder concept than reproductive biology and it covers not only individual organisms (plants) biology and ecology but also vegetative population regeneration processes in general. Without knowing the characteristics of a specie's reproductive biology, it's impossible to assess its current state and predict perspectives of its continued existence.

As a component of the reproductive process, seeds production, is an important indicator of species' viability in the specific conditions [2]. Factors related to characteristics of structure and development of reproductive organs play an important role in seeds play an important role in seeds formation. Genotype determines this characteristic $[3,4,5]$. The normal process of reproductive structures generation is disrupted under adverse conditions, which reduces plant productivity. As result of various external factors' influences, actual seeds productivity may decrease: earth and air temperature, humidity, photoperiod and light intensity, weather conditions of a particular season, corresponding to flowering and seed development period $[1,2,5]$. Processes of pollination and fertilization run into difficulties

*Corresponding author: karnaukhova-nina@,rambler.ru 
in the cladotypes, that existed under conditions different from modern. In this context, it's most important to research these processes in plant species threatened with extinction. This is important for development of the protection measures for rare (H. chaiyrakanicum Kurbatsky, $H$. minussinense B.Fedtsch., $H$. zundukii Peschkova) and endemic $(H$. austrosibiricum B.Fedtsch., $H$. turczaninovii Peschkova, $H$. sangilense Krasnob. et Timosch.) species in the Hedysarum L. genus under environmental conditions of their habitats in Southern Siberia.

\section{Materials and methods}

Research was conducted in 1983-2007 with the plants in natural phytocenosis on the territory of South Siberia.

Hedysarum austrosibiricum endemic to mountains of South Siberia is encountered on the alpine and sub-alpine meadows, in moss-lichen tundra, mixed herbs dwarf arctic birches and rocky stream gravel [7]. Material was collected on H. austrosibiricum in phytocenosis of high vein system in Kuznetsky Ala Tau around Ivanovskye lakes on the height of 1500 $\mathrm{m}$ above sea level in the vicinity of Priiskovy village in Ordgonykidzevsky area in Khakassia and on the height of 1700- $2100 \mathrm{~m}$ above sea level in Altai Republic.

Hedysarum chaiyrakanicum is a Tuvinan endemic, vulnerable species with 2 (U) status [8]. Famous from vicinity of Novy Shagonar city, Hyirkhan village and Kyslye Lakes (Turano-Uyukskaya hollow). Xerophyte calcephilus. Growing on limestone rocks.

Hedysarum sangilense - Dwells in mid-mountain vein system and undershelf of highland vein system on steppe, meadows, rocky hills, gravels, in sporadic forests of Tyva and Northern Mongolia. Material for researching of reproductive biology of endemic to Sangilen highlands collected in Erzinsky area of Tyva Republic in the middle reaches of Naryn river on height $1500 \mathrm{~m}$ above sea level in larch sparse forest and in tangled vegetations. Rare species with 3 (R) status endemic to island of Enisey steppes.

Hedysarum minussinense is encountered in steppes of Minusinsk, less frequently in Abakan (south of Krasnoyarsk territory). Dwells on rocky and crush stony slopes, rockslides, gramineous mixed herbs slopes, mainly on rocky patches [8]. Materials were collected in Bogdansky area of Khakassia (region of Znamenka village) and in the area of Ust-Abakan (region of Soviet Khakasia village) in the large caespitose steppe and in the two gramineous mixed herbs associations in rocky steppe, which are petrophytic variations of gramineous zonal large caespitose steppe.

Hedysarum turczaninovii endemic is encountered in steppe [7], forest-steppe vein systems on rocky, steppe slopes, in steppes of Kemerovo region, on south of Krasnoyarsk region, Irkutsk region, in Tyva Republic. Researched by us in an area of sub-taiga and forest-steppe vein systems of Khakasia vegetation: in sub-taiga vein system of vegetation of H. turczaninovii around the area of Tuym Shirynsky village in meadow sweet vetch-mixed herbs steppe (Tuym-1) and in rocky ling-gramineous-mixed herbs steppe (Tuym-2) as well as in forest-steppe vein system of vegetation around area of Kopyevo Ordgenikidze station in gramineous mixed herbs rocky steppe.

Hedysarum zundukii is a rare species ( $3 \mathrm{R})$, localized endemic to west coast of Baikal lake $[8,9]$. The bulk of its range is a territory approximately $8 \mathrm{~km}$ long and $0.5 \mathrm{~km}$ wide within an Olhinsky area of Irkutsk region [9]. Growing by single specimens in petrophytic mixed herbs steppes at steep calcium slopes and their round rocky, crushed stony plumes and on rockslides.

Conventional methods were used to research the family productivity $[2,10,11,12]$.

The number of flowers and set beans, number of seedbuds, number of inflorescences on the plant was calculated. On the basis of these data the researchers were counting the following indicators of seeds productivity: potential seeds productivity (PSP), real seeds 
productivity (RSP), seminalization percentage, sufficiency of pollination coefficient. (percent of beans to the number of flowers in inflorescences).

\section{Results and discussion}

Endemic species of South Siberian Hedysarum genus are vegetatively immobile, reproduction is strictly germiniparous. All species of Hedysarum genus have very peculiar structure of bean having overstretching between separated segments, in place where ripe fruit break down, but seeds don't spill out from a bean, like in the other leguminous plants, but germinate while remaining in the oral of the bean segment in second half of the summer (July - August). In the generative condition, sweet vetch develops varying amounts of generative shoots, vary in the number of multiflorous racemes, the number of flowers and beans in inflorescences (table 1,2). Notably, these indicators vary depending on the ontogenetical condition of specimens and growing condition of species (table 3).

Table 1. Hedysarum turczaninovii seeds productivity in different habitats.

\begin{tabular}{|l|c|c|c|}
\hline $\begin{array}{l}\text { Indicators: } \\
\text { number (on specimen), } \\
\text { pieces }\end{array}$ & $\begin{array}{c}\text { Kopyevo, } \\
\text { rocky steppe }\end{array}$ & $\begin{array}{c}\text { Tuym, } \\
\text { rocky steppe }\end{array}$ & $\begin{array}{c}\text { Tuym, } \\
\text { steppificated } \\
\text { meadow }\end{array}$ \\
\hline Generative shoots & $3.2 \pm 0.3$ & $2.5 \pm 0.2$ & $4.3 \pm 0.4$ \\
\hline Inflorescences & $6.0 \pm 0.6$ & $2.8 \pm 0.3$ & $4.5 \pm 0.5$ \\
\hline Flowers in the inflorescence & $16.3 \pm 0.8$ & $19.2 \pm 1.0$ & $16.3 \pm 1.2$ \\
\hline PSP* & 469.7 & 259.4 & 352.1 \\
\hline RSP & 219.8 & 112.0 & 144.6 \\
\hline C. seminalization, \% & 46.8 & 43.2 & 41.1 \\
\hline
\end{tabular}

Note: PSP - potential seeds productivity; RSP - real seeds productivity; $C$. seminalization, productivity coefficient $-R S P / P S P$.

Table 2. Hedysarum austrosibiricum seeds productivity in Kuznetsk Alatau and Mountain Altai.

\begin{tabular}{|c|c|c|c|c|}
\hline \multirow[b]{2}{*}{$\begin{array}{l}\text { Indicators: } \\
\text { number (on } \\
\text { specimen), pieces }\end{array}$} & \multicolumn{3}{|c|}{$\begin{array}{l}\text { Region of Kuznetsk Alatau. Priiskovy village, } 1500 \\
\text { m above sea level }\end{array}$} & \multirow{2}{*}{$\begin{array}{l}\text { Mountain Altai. } \\
\text { Kyzyl River } \\
\text { Valley. } 1900 \mathrm{~m} \text {. } \\
\text { above sea level. } \\
\text { Alpine lawn }\end{array}$} \\
\hline & $\begin{array}{l}\text { Crowberry family } \\
\text { crush stony slope } \\
\text { of northeast } \\
\text { exposition }\end{array}$ & $\begin{array}{l}\text { Flatland, } \\
\text { kurumoch }\end{array}$ & $\begin{array}{l}\text { Subalpine } \\
\text { meadow, slope } \\
\text { of the eastern } \\
\text { exposition }\end{array}$ & \\
\hline Generative shoots & $2.5 \pm 0.3$ & $4.8 \pm 1.0$ & $6.3 \pm 1.4$ & $4.7 \pm 0.3$ \\
\hline Inflorescences & $3.2 \pm 0.5$ & $7.2 \pm 1.4$ & $9.2 \pm 1.7$ & $6.0 \pm 0.5$ \\
\hline $\begin{array}{l}\text { Flowers in the } \\
\text { inflorescence }\end{array}$ & $12.9 \pm 0.9$ & $19.3 \pm 1.5$ & $18.3 \pm 0.9$ & $25.7 \pm 1.0$ \\
\hline PSP* & 214.6 & 732.6 & 877.8 & 801.8 \\
\hline RSP & 88.5 & 301.1 & 504.0 & 328.1 \\
\hline C. seminalization, $\%$ & 41.2 & 41.1 & 57.4 & 41.0 \\
\hline
\end{tabular}


Table 3. Hedysarum minussinense seeds productivity in young $\left(\mathrm{g}_{1}\right)$, middle-age $\left(\mathrm{g}_{2}\right)$ and old $\left(\mathrm{g}_{3}\right)$ generative specimens in different habitats in Znamenka village area.

\begin{tabular}{|l|c|c|c|c|c|c|}
\hline \multirow{2}{*}{$\begin{array}{l}\text { Sign: } \\
\text { number, pieces }\end{array}$} & \multicolumn{3}{|c|}{ Rocky steppe } & \multicolumn{3}{c|}{ Large caespitose steppe } \\
\cline { 2 - 7 } & $\mathrm{g}_{1}$ & $\mathrm{~g}_{2}$ & $\mathrm{~g}_{3}$ & $\mathrm{~g}_{1}$ & $\mathrm{~g}_{2}$ & $\mathrm{~g}_{3}$ \\
\hline $\begin{array}{l}\text { Generative } \\
\text { shoots }\end{array}$ & $6.0 \pm 1.0$ & $12.6 \pm 0.5$ & $4.9 \pm 1.0$ & $13.2 \pm 1.5$ & $54.3 \pm 10.4$ & $15.1 \pm 1.8$ \\
\hline Inflorescences & $10.0 \pm 2.1$ & $22.6 \pm 4.4$ & $7.4 \pm 1.2$ & $23.2 \pm 3.5$ & $110.2 \pm 20.6$ & $30.0 \pm 4.4$ \\
\hline $\begin{array}{l}\text { Flowers in the } \\
\text { inflorescence }\end{array}$ & $18.5 \pm 2.4$ & $18.0 \pm 2.3$ & $20.6 \pm 3.6$ & $19.9 \pm 1.0$ & $21.3 \pm 1.3$ & $17.5 \pm 1.3$ \\
\hline PSP* & 473.6 & 1041.4 & 391.8 & 1198.0 & 6126.4 & 1370.3 \\
\hline RSP & 200.5 & 453.2 & 149.0 & 254.4 & 1203.4 & 327.6 \\
\hline $\begin{array}{l}C . \text { seminalization, } \\
\%\end{array}$ & 42.3 & 43.5 & 38.0 & 21.2 & 19.6 & 23.9 \\
\hline
\end{tabular}

Percent of the set beans against the number of flowers (coefficient of pollination sufficiency or bean production efficiency) in endemic species oscillates from 35.3 to 90.7 $\% \%$ (table 4). The highest indicators noted for endemics $H$. austrosibiricum, $H$. turczaninovii и $H$. sangilense (90.7-74.1\%), minimum - in rare $H$. minussinense, $H$. chaiyrakanicum, H. zundukii (35.3-47.2\%). Effectivity of bean formation in researched endemics of the European part of Russia, known by literature data: H. daghestanicum Boiss. ex Rupr. 55.4-75.3; H. grandiflorum Pall., - 41.4-82.7 \%; H. rasoumovianum Fisch. et Helm - 57.3-66.1\%; H. gmelinii Ledeb. - 56.6 \% [13].

Table 4. Seeds productivity of endemic species of South Siberian Hedysarum genus (average indicators).

\begin{tabular}{|l|c|c|c|c|c|c|}
\hline $\begin{array}{l}\text { Indicators: } \\
\text { number (on } \\
\text { specimen), pieces }\end{array}$ & $\begin{array}{l}\text { H. austro- } \\
\text { sibiricum }\end{array}$ & $\begin{array}{l}\text { H. chaiy- } \\
\text { rakanicum }\end{array}$ & $\begin{array}{l}\text { H. minus- } \\
\text { sinense }\end{array}$ & $\begin{array}{l}\text { H. san- } \\
\text { gilense }\end{array}$ & $\begin{array}{l}\text { H. turc- } \\
\text { zaninovii }\end{array}$ & $\begin{array}{l}\text { H. zun- } \\
\text { dukii }\end{array}$ \\
\hline generative shoots & $3.9 \pm 0.5$ & $2.1 \pm 0.2$ & $24.8 \pm 3.0$ & $23.6 \pm 2.9$ & $3.1 \pm 0.2$ & $\begin{array}{c}10.9 \pm 1 . \\
0\end{array}$ \\
\hline $\begin{array}{l}\text { inflorescences } \\
\text { on a specimen }\end{array}$ & $5.6 \pm 0.7$ & $3.3 \pm 0.4$ & $62.8 \pm 6.0$ & $40.2 \pm 3.4$ & $4.2 \pm 0.3$ & $\begin{array}{c}16.0 \pm 1 . \\
3\end{array}$ \\
\hline $\begin{array}{l}\text { flowers in } \\
\text { specimens }\end{array}$ & $18.3 \pm 0.9$ & $14.9 \pm 1.0$ & $18.7 \pm 0.6$ & $19.1 \pm 0.6$ & $16.3 \pm 0.8$ & $\begin{array}{c}12.3 \pm 0 . \\
6\end{array}$ \\
\hline $\begin{array}{l}\text { beans in } \\
\text { inflorescence }\end{array}$ & $16.6 \pm 1.2$ & $5.5 \pm 0.5$ & $6.6 \pm 0.6$ & $14.2 \pm 0.9$ & $12.1 \pm 0.7$ & $5.8 \pm 0.4$ \\
\hline $\begin{array}{l}\text { C. pollination } \\
\text { sufficiency,\% }\end{array}$ & 90.7 & 36.9 & 35.3 & 74.1 & 74.2 & 47.2 \\
\hline $\begin{array}{l}\text { Seed-buds in the } \\
\text { flower }\end{array}$ & $5.3 \pm 0.1$ & $2.0 \pm 0.3$ & $3.1 \pm 0.2$ & $3.7 \pm 0.1$ & $4.8 \pm 0.1$ & $4.8 \pm 0.1$ \\
\hline $\begin{array}{l}\text { seeds in the } \\
\text { bean }\end{array}$ & $3.3 \pm 0.2$ & $0.8 \pm 0.2$ & $2.0 \pm 0.2$ & $2.7 \pm 0.1$ & $2.9 \pm 0.1$ & $0.8 \pm 0.1$ \\
\hline $\begin{array}{l}\text { PSP on } \\
\text { specimen }\end{array}$ & 485.0 & 52.4 & 3583.9 & 2889.3 & 328.7 & 755.7 \\
\hline $\begin{array}{l}\text { RSP on } \\
\text { specimen }\end{array}$ & 273.9 & 19.1 & 828.3 & 1564.8 & 148.2 & 73.8 \\
\hline $\begin{array}{l}\text { C. seminalization, } \\
\%\end{array}$ & 56.5 & 36.5 & 23.1 & 54.2 & 45.1 & 9.8 \\
\hline
\end{tabular}


Note: C. Pollination sufficiency - the percentage of set beans in an inflorescence

Potential seeds productivity values differ significantly from the actual productivity (Table 4). Since, in most cases RSP influenced by various factors turns out to be much lower than PSP, the percent of seminalization could serve as a reliable indicator of seeds reproduction "well-being" [2]. Coefficient of productivity is being used for the fuller profile of the reproductive process $C=\mathrm{RSP} / \mathrm{PSP}$ ( $\%$ seminalization). $C$ reflects the nature of interaction between organisms and habitat $[21,1]$.

It is well known that productivity coefficient in agrarian leguminous plants is rather low: for ten perennial species of leguminous it ranges from: 1.1 to $32.3 \%$ [2]. In the species we have researched, the highest percentage of complete seed formation (Table 4) is noted for such endemics as $H$. austrosibiricum, $H$. sangilense and $H$. turczaninovii (56.5$45.1 \%$ ), minimum - in rare H. zundukii, H. minussinense and H. chaiyrakanicum (9.8-36.5 $\%$ ). A decline in the number of set seeds compared to the quantity of seed-buds can be produced by several obvious causes, among which is embryogenesis disorders, adverse conditions of outside environment in period of the generative organs and seeds formation, insufficient number of pollinating agents and damage of the set seeds by insects.

Thus, integrated research conducted in different populations has yielded figures about current status of reproductive process of endemic species within the Hedysarum genus. The highest rates of seed set efficiencies and set of complete seeds has been noted in endemics and hemiendemics $H$. austrosibiricum, H. sangilense and H. turczaninovii, the minimum rate has been discovered in rare narrow local endemic species $H$. zundukii, $H$. minussinense and $H$. chaiyrakanicum.

The study was performed as a state assignment for the Central Siberian Botanical Gardens SB RAS (state registration number AAAA-A17-117012610052-2 and AAAA-A17-117012610051-5) and the Altai Federal scientific center of agrobiotechnology (AAAA-A19-119092490021-6), as well as with the financial support from the Russian Foundation for Basic Research project 20-44-040002 r_a.

\section{References}

1. R. E. Levina, Reproductive biology of seed plants (Problem review) (Moscow, 1981)

2. I. V. Vaynagii, Bot. J. 59, 6 (1975)

3. D. Charlesworth, Trends Ecol. Evol., 4 (1989)

4. L. I. Orel, E. V. Semyonova, Bot. J. 74, 4 (1989)

5. L. I. Orel, E. B. Kazachkovskaya, Bot. J. 76, 2 (1991)

6. Siberian flora, 9 (Novosibirsk, 1994)

7. Red book of Tyva Republic: plants (Novosibirsk, 1999)

8. Red book of the Russian Federation (plants and mushroom) (Moscow, 2008)

9. Red book of Irkutsk region: Vascular plants (Irkutsk, 2001)

10. T. A. Rabotnov, Field geobotanic. 2 (1960)

11. I. V. Vaynagii, Veg. resources. 9, 2 (1973)

12. Y. A. Zlobin, Embryology of flowering plants. (SPb, 2000)

13. S. M. Zubairova, Basic research., 6, 2 (2013) 